\title{
ANALISIS KEPUASAN PELANGGAN PADA BENGKEL ANTO MOTOR PEKANBARU
}

\author{
M. Rachmadi \\ (Dosen Fakultas Ekonomi dan Ilmu Sosial UIN Suska Riau)
}

\begin{abstract}
ABSTRAK
Penelitian ini dilakukan Pada Bengkel Anto Motor Pekanbaru. Penulis melakukan penelitian ini untuk mengetahui faktor-faktor apa yang mempengaruhi kepuasan pelanggan pada Bengkel Anto Motor Pekanbaru .

Hipotesis penelitian ini dirumuskan sebagai berikut : "diduga bahwa tingkat kepuasan pelanggan pada Bengkel Anto Motor Pekanbaru telah sesuai dengan harapan pelanggan”.

Penelitian ini memerlukan data primer dan data sekunder, dalam penelitian ini teknik pengambilan sampel secara Purposive Sampling, dengan menggunakan rumus Slovin, dimana teknik penentuan sampel dengan pertimbangan tertentu yaitu orang yang benar-benar pelanggan Bengkel Anto Motor Pekanbaru. Dalam melakukan analisis data penulis menggunakan metode analisis Deskriptif kuantitatif dengan menggunakan Importance Performance Analysis (Analisis Tingkat Kepentingan dan kinerja/kepuasan pelanggan).

Pada penelitian ini variabel yang dibahas yaitu Bukti fisik(tangible), Jaminan(assurance), Kehandalan(realibility), Ketanggapan(responsiveness) dan Empati(emphaty)

Dari penelitian ini diperoleh hasil sebagai berikut : Bukti fisik (tangible), Jaminan (assurance), Kehandalan (reliability), Ketanggapan (responsiveness) dan Empati (emphaty) mempengaruhi kepuasan Pelanggan pada Bengkel Anto Motor Pekanbaru, hal ini terlihat dari hasil olahan data, ini berarti variabel-variabel tersebut memiliki pengaruh yang erat secara parsial terhadap kepuasan pelanggan pada Bengkel Anto Motor Pekanbaru.
\end{abstract}

Kata kunci: Bukti fisik, Jaminan, Kehandalan, Ketanggapan dan Empati

\section{PENDAHULUAN}

Di negara Indonesia ini sudah sangat cukup maju dan telah banyak perusahaan di Indonesia ini yang bergerak dalam industri otomotif. Di dalam industri otomotif ini terjadi persaingan yang sangat ketat. Untuk dapat bertahan suatu perusahaan otomotif harus menyediakan produk-produk yang berkualitas agar pelanggan tidak lari ke bengkel lain. Selain produk tersebut harus didukung juga oleh pelayanan jasa yang baik.

Layanan jasa tersebut dapat memberikan keuntungan. Bengkel Anto Motor Pekanbaru selalu berusaha meningkatkan kualitas pelayanan agar dapat memuaskan pelanggannya, yaitu dengan cara berusaha mengetahui perilaku-perilaku konsumen, membeli serta memakai barang atau jasa yang ditawarkan. Oleh karena itu, informasi yang dibutuhkan perusahaan tidak saja menyangkut tentang produk, model dan jasa apa saja yang dibutuhkan oleh pelanggan, tapi juga termasuk alasan mengapa membeli dan memakai produk dan jasa tersebut. Hal ini perlu dilakukan pada hakekatnya keinginan dan selera pelanggan selalu berubah dari waktu ke waktu.

Pelanggan akan menggunakan jasa bengkel lain apabila dalam pelayanan diatas tidak dilakukan dan juga bisa dapat mengurangi pendapatan dan bahkan dapat mengakibatkan bengkel kehilangan pelanggan, oleh karena itu apa-apa saja yang menjadi kelemahan dari perusahaan bisa diatasi dengan 
baik sehingga tidak kehilangan pelanggan, bahkan jika kemungkinan dapat menambah pelanggan yang baru.

Bengkel Anto Motor Pekanbaru merupakan salah satu bengkel yang memberikan kontribusi positif terhadap perkembangan transportasi dan bengkel ini telah berdiri semenjak tahun 2009.

Maka dari itu untuk mengetahui data pelanggan yang mendapat pelayanan pada Bengkel Anto Motor Pekanbaru pada 5 tahun terakhir dapat dilihat pada tabel berikut ini :

\section{Tabel 1}

Perkembangan Pengguna Jasa Pada Bengkel Anto Motor Pekanbaru Tahun 2009-2013

\begin{tabular}{|c|c|c|c|c|c|c|}
\hline \multirow{2}{*}{$\begin{array}{l}\mathbf{N} \\
\mathbf{o}\end{array}$} & \multirow{2}{*}{$\begin{array}{l}\text { Bidang Jasa } \\
\text { (Pelayanan) }\end{array}$} & \multicolumn{5}{|c|}{ Dalam Orang } \\
\hline & & 2009 & 2010 & 2011 & 2012 & 2013 \\
\hline \multirow[t]{2}{*}{1} & Pekerjaan & & & & & \\
\hline & $\begin{array}{l}\text { Berat } \\
\text { a. Bongkar / } \\
\text { pasang } \\
\text { Mesin }\end{array}$ & 27 & 31 & 39 & 55 & 60 \\
\hline \multirow[t]{6}{*}{2} & b. Press Body & 15 & 18 & 21 & 27 & 30 \\
\hline & \multicolumn{6}{|l|}{ Pekerjaan } \\
\hline & a. Ganti Oli & 150 & 268 & 389 & 406 & 424 \\
\hline & $\begin{array}{l}\text { b. Stel } \\
\text { Karburator }\end{array}$ & 278 & 302 & 367 & 405 & 447 \\
\hline & $\begin{array}{l}\text { c. Ganti } \\
\text { kanvas } \\
\text { rem }\end{array}$ & 175 & 258 & 309 & 380 & 408 \\
\hline & d. Stel klep & 185 & 220 & 294 & 312 & 324 \\
\hline \multicolumn{2}{|r|}{ Jumlah } & 830 & 1097 & 1419 & 1585 & 1693 \\
\hline
\end{tabular}

Sumber : Bengkel Anto Motor Pekanbaru

Menurut data diatas dapat dilihat bahwa pada setiap tahunnya jumlah pelanggan Bengkel Anto Motor Pekanbaru terjadi peningkatan.

Berdasarkan latar belakang masalah diatas, maka penulis dapat merumuskan masalah sebagai berikut : "Bagaimanakah Tingkat kepuasan Pelanggan pada Bengkel Anto Motor Pekanbaru.

Tujuan Penelitian ini untuk mengetahui tingkat kepuasan pelanggan pada Bengkel Anto Motor Pekanbaru.

\section{TINJAUAN PUSTAKA}

\section{Pengertian Kepuasan Pelanggan}

Beberapa pengertian para ahli tentang kepuasan pelanggan bila dilihat secara sepintas menunjukkan perbedaan antara yang satu dengan yang lainnya, akan tetapi mempunyai tujuan yang sama. Beberapa pendapat ahli tentang kepuasan pelanggan :

Menurut Lina Anatan (2008;76) kepuasan pelanggan adalah sebagai tingkat perasaan seseorang setelah membandingkan kinerja atau outcome yang dirasakan dengan harapan-harapan terhadap produk tersebut.

Menurut Richard Oliver Kepuasan pelanggan adalah respon pemenuhan dari konsumen, hasil penilaian dari konsumen bahwa produk atau layanan telah memberikan tingkat kenikmatan dimana tingkat pemenuhan ini bisa lebih atau kurang (Handi Irawan ; 2009; 3).

Kepuasan Pelanggan di definisikan sebagai respon pelanggan terhadap tingkat kepentingan sebelumnya dan kinerja aktual yang dirasakannya setelah pemakaiannya (Freddy Rangkuti, 2006 ;30).

Supaya layanan dapat memuaskan pelanggan, petugas yang melayani harus memenuhi 4 kriteria pokok yaitu : (Moenir, 2000:197)

1. Tingkah laku yang sopan

2. Cara penyampaian sesuatu yang berkaitan dengan apa yang seharusnya diterima oleh orang yang bersangkutan.

3. Waktu menyampaikan yang tepat

4. Keramahtamahan.

Jadi, kepuasan atau tidak kepuasan pelanggan adalah respon pelanggan terhadap evaluasi ketidaksesuaian (disconfirmation) yang dirasakan antara harapan sebelumnya dengan kinerja aktual yang dirasakan pemakainya

Faktor-faktor yang Mempengaruhi Tingkat Kepuasan Pelanggan

Menurut Zeithamal dan Bitner faktor utama penentu kepuasan pelanggan adalah 
persepsi pelanggan terhadap kualitas jasa (Rambat Lupiyoadi dan A. Hamdani, 2006:192).

Menurut Christoper Lovelock terdapat lima kriteria yang pada dasarnya identik dengan beberapa jenis jasa yang memberikan kepuasan kepada para pelanggan (Freddy Rangkuti, 2006:18), berikut llima kriteria tersebut yaitu :

a. Bukti Fisik (Tangible) yaitu penampilan fasilitas fisik, peralatan, personel dan alatalat komunikasi. Bukti fisik ini sangat berpengaruh karena memiliki hasil yang nyata dari pekerjaan tersebut, keharmonisan interior dan eksterior ruangan dan terkesan rapi, indah sejuk, asri dan teratur, merupakan salah satu bentuk jasa yang ditawarkan pada konsumen atau pelanggan.

b. Jaminan (Assurance) yaitu, pengetahuan dan kemampuan karyawan untuk melayani dengan rasa percaya diri. Beberapa aspek dari jaminan yaitu :

1. Keramahan

2. Rasa percaya diri dan jaminan keamanan terhadap penyedia jasa.

3. Ketrampilan dan pengetahuan karyawan.

c. Kehandalan (Reliability) yaitu, dimensi yang mengukur kehandalan dari perusahaan atau penyedia jasa dalam memberikan pelayanan kepada pelanggan. Kehandalan juga menentukan kepuasan pelanggan.

d. Ketanggapan (Responsiveness) yaitu, kemampuan karyawan untuk membantu konsumen menyediakn jasa dengan cepat sesuai dengan yang diinginkan oleh konsumen. Dipengaruhi oleh :

1. Kecepatan Pelayanan,

2. Komunikasi tentang pelanggan tentang proses pelayanan,

3. Ketulusan menjawab pertanyaan atau permintaan pelanggan

4. Sikap kesigapan karyawan.

e. Emphati (Emphaty) yaitu, karyawan harus memberikan perhatian secara individual kepada konsumen dan mengerti kebutuhan konsumen.

\subsection{Kualitas Pelayanan/Jasa}

Kualitas merupakan suatu yang harus dikerjakan dengan baik. Aplikasi kualitas sebagai sifat dari penampilan produk atau kinerja merupakan bagian utama strategi perusahaan dalam rangka meraih keunggulan yang berkesinambungan.

Definisi kualitas jasa terpusat pada upaya pemenuhan kebutuhan dan keingainan pelanggan serta ketepatan penyampaiannya untuk mengimbangi harapan pelanggan (Tjiptono,2000: 51).

Kualitas jasa merupakan tingkat kesempurnaan yang diharapkan dan pengendalian atas kesempurnaan tersebut untuk memenuhu keinginan pelanggan

(Wykof dalam Tjiptono, 2005 : 52).

Selanjutnya menurut Barata (2004:37), kualitas layanan terbagi dua, yaitu

1. Kualitas Layanan Internal

Berkaitan dengan interaksi jajaran pegawai organisasi/perusahaan dengan berbagai fasilitas yang tersedia. Faktor yang mempengaruhi kualitas pelayanan internal, antara lain :

a. Pola manajemen umum organisasi / perusahaan

b. Penyediaan fasilitas pendukung

c. Pengembangan Sumber Daya Manusia

d. Iklim kerjadan keselarasan hubungan kerja

e. Pola insentif

Jika faktor-faktor diatas dikembangkan, loyalitas dan integritas pada diri masingmasing pegawai akan mampu untuk mengembangkan pelayanan yang terbaik diantara mereka.

2. Kualitas layanan eksternal

Mengenai kualitas layanan kepada pelanggan eksternal, kualitas layanan ditentukan oleh beberapa faktor, antara lain : (2004:37-38),

a. Yang berkaitan dengan penyediaan jasa 
1) Pola layanan dan tata cara penyediaan / pembentukan jasa tertentu.

2) Pola layanan distribusi jasa

3) Pola layanan penjualan jasa

4) Pola layanan dalam penyampaian jasa

b. Yang berkaitan dengan penyediaan barang

1) Pola layanan dan pembuatan barang berkualitas atau penyediaan barang berkulitas.

2) Pola layanan pendistribusian barang

3) Pola layanan penjualan barang

4) Pola layanan purna jual

Keempat jenis layanan diatas dapat disebut sebagai kinerja pelayanan (Service Performance)

\subsection{Pengertian dan Karakteristik Jasa}

Terdapat lima karakteristik utama jasa bagi pembeli utamanya (Tjiptono,2004:18) :

1. Intangibility (tidak berwujud) Jasa berbeda dengan barang. Bila barang merupakan suatu objek, alat, atau benda, maka jasa adalah suatu perbuatan, tindakan, pengalaman, proses, kinerja (perfomance), atau usaha. Oleh sebab itu, jasa tidak dapat dilihat, dirasa, dicium, didengar, atau diraba sebelum dibeli dan dikonsumsi.

2. Variability / Heterogeneity (berubah-ubah) Jasa bersifat variabel karena merupakan non-standarized output, artinya banyak variasi bentuk, kualitas, dan jenis tergantung kepada siapa, kapan, dan dimana jasa tersebut diproduksi.

3. Perishability (tidak tahan lama) Jasa tidak tahan lama dan tidak dapat disimpan. Lack Of Ownership merupakan perbedaan dasar antara jasa dan barang. Pada pembelian barang, konsumen memiliki hak penuh atas penggunaan dan manfaat produk yang dibelinya.

\section{Variabel Penelitian}

Pada penelitian ini peneliti menggunakan teori yang dikemukakan oleh Freddy Rangkuti (2006:18) terhadap pengukuran pada kepuasan pelanggan adalah sebagai berikut :
1. Bukti fisik (tangible)
2. Jaminan (assurance)
3. Kehandalan (reliability)
4. Ketanggapan (responsiveness)
5. Empati (emphaty)

\section{Populasi dan Sampel}

Didasari dari jumlah populasi data konsumen pengguna jasa pada Tahun 2013, yaitu sebanyak 1.693 orang. Maka populasi tersebut menjadikan dasar untuk mendapatkan sampel penelitian.

Sampel dalam penelitian ini adalah diambil dari jumlah populasi atau konsumen pengguna jasa pada Bengkel Anto Motor Pekanbaru pada tahun 2013 sebanyak 1.693 orang. Adapun cara untuk menentukan jumlah sampel menggunakan rumus Slovin (Umar, 2003 : 146).

$$
n=\frac{N}{1+N e^{2}}
$$

Jadi, jumlah sampel yang diperlukan sebesar 94 Orang Pelanggan Bengkel Anto Motor Pekanbaru.

Sedangkan metode pengambilan sampel yang digunakan adalah metode Purposive Sampling, dimana teknik penentuan sampel dengan pertimbangan tertentu, yaitu orang tersebut benar-benar ahli dalam bidangnya. (Sugiono, 2006: 78).

\section{Analisis Data}

Dalam penelitian ini, penulis menggunakan metode analisis deskriptif kuantitatif. Untuk menjawab rumusan masalah, digunakan Importance-Performance Analysis atau Analisis Tingkat Kepentingan dan kinerja/kepuasan pelanggan.

Dalam penelitian ini terdapat dua variabel yang diwakilkan oleh huruf $\mathrm{X}$ dan Y. X adalah tingkat kinerja bengkel AntoMotor Pekanbaru yang dapat memberikan kepuasan pada konsumen (kenyataan yang dirasakan konsumen) sedangakan $\mathrm{Y}$ adalah kepentingan 
konsumen (harapan yang diinginkan oleh konsumen). Rumus yang digunakan :

$$
\mathrm{Tki}=\frac{\mathrm{Xi}}{\mathrm{Yi}} \times 100 \%
$$

Selanjutnya sumbu mendatar (X) akan diisi oleh skor tingkat pelaksanaan, sedangkan sumbu tegak (Y) akan diisi oleh skor tingkat kepentingan. Dalam penyederhanaan rumus, maka untuk setiap faktor yang mempengaruhi kepuasan pelanggan dihitung dengan :

$\overline{\mathrm{X}}=\frac{\sum \mathrm{Xi}}{\mathrm{n}} \quad \overline{\mathrm{Y}}=\frac{\sum \mathrm{Yi}^{\mathrm{i}}}{\mathrm{n}}$

$\mathrm{X}=$ skor rata-rata tingkat pelaksanaan / kepuasan

$\mathrm{Y}=$ skor rata-rata tingkat kepentingan

$\mathrm{n}=$ jumlah responden

Perhitungan tersebut kemudian digambatkan dalam diagram cartesius sebagai berikut :

Gambar 1

Diagram Cartesius Analisis Tingkat Kepentingan dan Kinerja / Kepuasan Pelanggan

Kepentingan

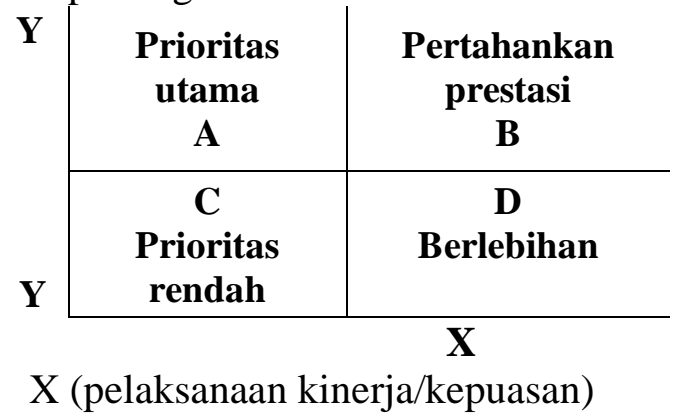

Keterangan :

A. Menunjukkan faktor atau atribut yang dianggap mempengaruhi kepuasan pelanggan, termasuk unsur-unsur jasa yang dianggap sangat penting namun manajemnen belum melaksanakan sesuai keinginan konsumen. Sehingga mengecawakan atau tidak memuaskan.

B. Menunjukkan unsur jasa pokok yang telah berhasil dilaksanakan. Untuk itu wajib dipertahankan. Dianggap sangat penting dan sangat memuaskan.

C. Menunjukkan beberapa faktor yang kurang penting pengaruhnya bagi pelanggan, pelaksanaan oleh perusahaan biasa-biasa saja. Dianggap kurang penting dan kurang memuaskan.

Menunjukkan faktor yang mempengaruhi pelanggan kurang penting, akan tetapi pelaksanaanya berlebihan. Dianggap kurang penting tetapi sangat memuaskan.

\section{HASIL DAN PEMBAHASAN}

Didalam hal ini akan diuraikan hasil penelitian dengan menggunakan analisa deskriptif kualitatif. Data yang ada diperoleh dengan memberikan daftar pertanyaan dalam bentuk questioner kepada konsumen sebanyak 94 orang, selanjutnya data yang diperoleh ditabulasikan untuk dianalisa secara deskriptif kualitatif.

Berikut penjelasan mengenai hasil dari penelitian.

\section{A. Identitas Responden}

Tabel 2

Tingkat usia responden Pada Bengkel Anto Motor Pekanbaru

\begin{tabular}{|c|c|c|c|}
\hline No & Usia & $\begin{array}{c}\text { Jumlah } \\
\text { Responden }\end{array}$ & $\begin{array}{c}\text { Persentase } \\
(\mathbf{\%})\end{array}$ \\
\hline 1 & $15-20$ & 16 & 17,02 \\
\hline 2 & $21-40$ & 23 & 24,47 \\
\hline 3 & $41-50$ & 38 & 40,42 \\
\hline 4 & $51-60$ & 17 & 18,09 \\
\hline Jlh & & $\mathbf{9 4}$ & $\mathbf{1 0 0}$ \\
\hline
\end{tabular}

Sumber : Data Olahan 2013

\section{B. Jenis Kelamin}

Tabel 3

Jenis kelamin responden Pada Bengkel Anto Motor Pekanbaru

\begin{tabular}{|c|c|c|c|}
\hline No & $\begin{array}{c}\text { Jenis } \\
\text { kelamin }\end{array}$ & $\begin{array}{c}\text { Jumlah } \\
\text { Responden }\end{array}$ & $\begin{array}{c}\text { Persentase } \\
(\boldsymbol{\%})\end{array}$ \\
\hline 1 & PRIA & 69 & 73,40 \\
\hline 2 & WANITA & 25 & 26,60 \\
\hline Jlh & & $\mathbf{9 4}$ & $\mathbf{1 0 0}$ \\
\hline
\end{tabular}

Sumber : Data Olahan 2013 


\section{JenisPekerjaan}

Tabel 4

Jenis Pekerjaan Responden Pada Bengkel Anto Motor Pekanbaru

\begin{tabular}{|c|c|c|c|}
\hline No & Pekerjaan & $\begin{array}{c}\text { Jumlah } \\
\text { Responden }\end{array}$ & $\begin{array}{c}\text { Persentase } \\
(\boldsymbol{\%})\end{array}$ \\
\hline 1 & PNS & 38 & 40,42 \\
\hline 2 & Wiraswasta & 30 & 31,91 \\
\hline 3 & $\begin{array}{c}\text { Ibu rumah } \\
\text { tangga }\end{array}$ & 8 & 8,52 \\
\hline 4 & Pelajar & 18 & 19,15 \\
\hline Jlh & & $\mathbf{9 4}$ & $\mathbf{1 0 0}$ \\
\hline
\end{tabular}

Sumber : Data Olahan 2013

D. JenjangPendidikan

Tabel 5

Data Pendidikan Terakhir RespondenPada Bengkel Anto Motor Pekanbaru

\begin{tabular}{|c|c|c|c|}
\hline No & Pendidikan & $\begin{array}{c}\text { Jumlah } \\
\text { Responden }\end{array}$ & $\begin{array}{c}\text { Persentase } \\
(\mathbf{\%})\end{array}$ \\
\hline 1 & Sarjana & 24 & 25,54 \\
\hline 2 & SLTA & 53 & 56,38 \\
\hline 3 & SLTP & 8 & 8,51 \\
\hline 4 & SD & 9 & 9,57 \\
\hline Jlh & & $\mathbf{9 4}$ & $\mathbf{1 0 0}$ \\
\hline
\end{tabular}

Sumber : Data Olahan 2013

Data Hasil Penelitian Analisis Variabel Tangible (Bukti Fisik) Tabel 6

Kenyataan dan Harapan responden terhadap Lokasi yang strategis

\begin{tabular}{|c|c|c|c|c|c|c|}
\hline $\begin{array}{c}\text { Kondi } \\
\text { si }\end{array}$ & $\begin{array}{c}\text { Sang } \\
\text { at } \\
\text { Pent } \\
\text { ing }\end{array}$ & $\begin{array}{c}\text { Pent } \\
\text { ing }\end{array}$ & $\begin{array}{c}\text { Cuk } \\
\text { Pent } \\
\text { ing }\end{array}$ & $\begin{array}{c}\text { Kur } \\
\text { ang } \\
\text { Penti } \\
\text { ng }\end{array}$ & $\begin{array}{c}\text { Tida } \\
\text { k } \\
\text { pent } \\
\text { ing }\end{array}$ & $\begin{array}{c}\text { Bo } \\
\text { bot }\end{array}$ \\
\hline $\begin{array}{c}\text { Kenya } \\
\text { taan }\end{array}$ & 47 & 19 & 23 & 5 & 0 & 390 \\
\hline $\begin{array}{c}\text { Harap } \\
\text { an }\end{array}$ & 61 & 21 & 8 & 4 & 0 & 421 \\
\hline
\end{tabular}

Sumber : Data Olahan 2013

Dari data diatas didapat hasil jawaban responden diperoleh tingkat kesesuaiannya $=$
$(390 / 421)$ x $100 \%=\mathbf{9 3 , 6 4 \%}$. Diartikan kesesuai sebesar 93,64\% terhadap lokasi yang strategis tempat keberapaan Bengkel Anto Motor Pekanbaru.

Tabel 7

Kenyataan dan Harapan responden terhadap Kondisi bengkel yang menarik perhatian dan kokoh

\begin{tabular}{|c|c|c|c|c|c|c|}
\hline $\begin{array}{c}\text { Kondi } \\
\text { si }\end{array}$ & $\begin{array}{c}\text { Sang } \\
\text { at } \\
\text { pent } \\
\text { ing }\end{array}$ & $\begin{array}{c}\text { Pent } \\
\text { ing }\end{array}$ & $\begin{array}{c}\text { Cuk } \\
\text { up } \\
\text { Pent } \\
\text { ing }\end{array}$ & $\begin{array}{c}\text { Kur } \\
\text { ang } \\
\text { penti } \\
\text { ng }\end{array}$ & $\begin{array}{c}\text { Tida } \\
\mathbf{k} \\
\text { pent } \\
\text { ing }\end{array}$ & $\begin{array}{c}\text { Bo } \\
\text { bot }\end{array}$ \\
\hline $\begin{array}{c}\text { Kenya } \\
\text { taan }\end{array}$ & 35 & 29 & 21 & 9 & 0 & 372 \\
\hline $\begin{array}{c}\text { Harap } \\
\text { an }\end{array}$ & 51 & 20 & 20 & 3 & 0 & 401 \\
\hline
\end{tabular}

Sumber : Data Olahan 2013

Dari data diatas didapat hasil jawaban responden diperoleh tingkat kesesuaiannya $=$ $(372 / 401)$ x $100 \%=\mathbf{9 2 , 7 7 \%}$. Diartikan kesesuain sebesar 93,64\% terhadap kondisi Bengkel Anto Motor Pekanbaru yang memberikan tampilan menarik perhatian dan kokoh.

Tabel 8

Kenyataan dan Harapan responden terhadap kelengkapan fasilitas seperti Spare Part dan peralatan perbaikan

\begin{tabular}{|c|c|c|c|c|c|c|}
\hline $\begin{array}{c}\text { Kond } \\
\text { isi }\end{array}$ & $\begin{array}{c}\text { San } \\
\text { gat } \\
\text { pent } \\
\text { ing }\end{array}$ & $\begin{array}{c}\text { Pent } \\
\text { ing }\end{array}$ & $\begin{array}{c}\text { Cuk } \\
\text { Pent } \\
\text { ing }\end{array}$ & $\begin{array}{c}\text { Kur } \\
\text { ang } \\
\text { penti } \\
\text { ng }\end{array}$ & $\begin{array}{c}\text { Tida } \\
\text { k } \\
\text { pent } \\
\text { ing }\end{array}$ & $\begin{array}{c}\text { Bo } \\
\text { bot }\end{array}$ \\
\hline $\begin{array}{c}\text { Keny } \\
\text { ataan }\end{array}$ & 39 & 34 & 10 & 11 & 0 & 383 \\
\hline $\begin{array}{c}\text { Harap } \\
\text { an }\end{array}$ & 55 & 29 & 6 & 4 & 0 & 417 \\
\hline
\end{tabular}

Sumber : Data Olahan 2013

Dari data diatas didapat hasil jawaban responden diperoleh tingkat kesesuaiannya $(383 / 417)$ x $100 \%=\mathbf{9 1 , 8 5 \%}$. Diartikan kesesuaian sebesar $\mathbf{9 1 , 8 5 \%}$ terhadap kelengkapan fasilitas seperti spare part dan peralatan perbaikan pada Bengkel AntoMotor Pekanbaru. 
Tabel 9

Kenyataan dan Harapan responden terhadap fasilitas dibandingkan bengkel lain

\begin{tabular}{|c|c|c|c|c|c|c|}
\hline $\begin{array}{c}\text { Kond } \\
\text { isi }\end{array}$ & $\begin{array}{c}\text { San } \\
\text { gat } \\
\text { pent } \\
\text { ing }\end{array}$ & $\begin{array}{c}\text { Pent } \\
\text { ing }\end{array}$ & $\begin{array}{c}\text { Cuk } \\
\text { up } \\
\text { Pent } \\
\text { ing }\end{array}$ & $\begin{array}{c}\text { Kur } \\
\text { ang } \\
\text { Pent } \\
\text { ing }\end{array}$ & $\begin{array}{c}\text { Tida } \\
\text { k } \\
\text { pent } \\
\text { ing }\end{array}$ & $\begin{array}{c}\text { Bo } \\
\text { bot }\end{array}$ \\
\hline $\begin{array}{c}\text { Keny } \\
\text { ataan }\end{array}$ & 44 & 30 & 14 & 6 & 0 & 394 \\
\hline $\begin{array}{c}\text { Harap } \\
\text { an }\end{array}$ & 60 & 23 & 9 & 2 & 0 & 423 \\
\hline
\end{tabular}

Sumber: Data Olahan 2013

Dari data diatas didapat hasil jawaban responden diperoleh tingkat kesesuaiannya $=$ $(394 / 423) \times 100 \%=\mathbf{9 3 , 1 4 \%}$. Diartikan kesesuaian sebesar $\mathbf{9 3 , 1 4 \%}$ terhadap kelengkapan fasilitas dibandingkan bengkel lain

\section{Analisis Variabel Assurance (Jaminan)}

Tabel 10

Kenyataan dan Harapan responden terhadap Mekanik dengan jumlah yang memadai

\begin{tabular}{|c|c|c|c|c|c|c|}
\hline $\begin{array}{c}\text { Kondi } \\
\text { si }\end{array}$ & $\begin{array}{c}\text { Sang } \\
\text { at } \\
\text { Pent } \\
\text { ing }\end{array}$ & $\begin{array}{c}\text { Pent } \\
\text { ing }\end{array}$ & $\begin{array}{c}\text { Cuk } \\
\text { Pent } \\
\text { ing }\end{array}$ & $\begin{array}{c}\text { Kur } \\
\text { ang } \\
\text { penti } \\
\text { ng }\end{array}$ & $\begin{array}{c}\text { Tida } \\
\mathbf{k} \\
\text { pent } \\
\text { ing }\end{array}$ & $\begin{array}{c}\text { Bo } \\
\text { bot }\end{array}$ \\
\hline $\begin{array}{c}\text { Kenya } \\
\text { taan }\end{array}$ & 45 & 25 & 14 & 10 & 0 & 387 \\
\hline $\begin{array}{c}\text { Harap } \\
\text { an }\end{array}$ & 55 & 30 & 5 & 4 & 0 & 418 \\
\hline
\end{tabular}

Sumber: Data Olahan 2013

Dari data diatas didapat hasil jawaban responden diperoleh tingkat kesesuaiannya $=$ $(387 / 418) \times 100 \%=\mathbf{9 2 , 5 8 \%}$. Diartikan kesesuaian sebesar $\mathbf{9 2 , 5 8 \%}$ terhadap pada Bengkel Anto Motor Pekanbaru.

Tabel 11

Kenyataan dan Harapan responden terhadap Mekanik yang sigap melayani pelanggan

\begin{tabular}{|c|c|c|c|c|c|c|}
\hline $\begin{array}{l}\text { Kondi } \\
\text { si }\end{array}$ & $\begin{array}{c}\text { Sang } \\
\text { at } \\
\text { Pent } \\
\text { ing }\end{array}$ & $\begin{array}{c}\text { Pent } \\
\text { ing }\end{array}$ & $\begin{array}{c}\text { Cuk } \\
\text { up } \\
\text { Pent } \\
\text { ing }\end{array}$ & $\begin{array}{c}\text { Kur } \\
\text { ang } \\
\text { Penti } \\
\text { ng }\end{array}$ & $\begin{array}{c}\text { Tida } \\
\text { k } \\
\text { pent } \\
\text { ing }\end{array}$ & $\begin{array}{l}\text { Bo } \\
\text { bot }\end{array}$ \\
\hline
\end{tabular}

\begin{tabular}{|c|c|c|c|c|c|c|}
\hline $\begin{array}{c}\text { Kenya } \\
\text { taan }\end{array}$ & 48 & 25 & 8 & 13 & 0 & 365 \\
\hline $\begin{array}{c}\text { Harap } \\
\text { an }\end{array}$ & 61 & 10 & 15 & 8 & 0 & 406 \\
\hline
\end{tabular}

Sumber : Data Olahan 2013

Dari data diatas didapat hasil jawaban responden diperoleh tingkat kesesuaiannya $=$ $(405 / 426) \times 100 \%=89,90 \%$. Diartikan kesesuaian sebesar $\mathbf{8 9 , 9 0 \%}$ terhadap mekanik yang sigap melayani pelanggan pada Bengkel Anto Motor Pekanbaru.

Tabel 12

Kenyataan dan Harapan responden terhadap Mekanik yang memiliki pengetahuan yang baik tentang kendaraan

\begin{tabular}{|c|c|c|c|c|c|c|}
\hline $\begin{array}{c}\text { Kondi } \\
\text { si }\end{array}$ & $\begin{array}{c}\text { Sang } \\
\text { at } \\
\text { Pent } \\
\text { ing }\end{array}$ & $\begin{array}{c}\text { Pent } \\
\text { ing }\end{array}$ & $\begin{array}{c}\text { Cuk } \\
\text { up } \\
\text { Pent } \\
\text { ing }\end{array}$ & $\begin{array}{c}\text { Kur } \\
\text { ang } \\
\text { Penti } \\
\text { ng }\end{array}$ & $\begin{array}{c}\text { Tida } \\
\mathbf{k} \\
\text { pent } \\
\text { ing }\end{array}$ & $\begin{array}{c}\text { Bo } \\
\text { bot }\end{array}$ \\
\hline $\begin{array}{c}\text { Kenya } \\
\text { taan }\end{array}$ & 52 & 20 & 12 & 10 & 0 & 396 \\
\hline $\begin{array}{c}\text { Harap } \\
\text { an }\end{array}$ & 61 & 11 & 18 & 4 & 0 & 411 \\
\hline
\end{tabular}

Sumber : Data Olahan 2013

Dari data diatas didapat hasil jawaban responden diperoleh tingkat kesesuaiannya = $(396 / 411) \times 100 \%=96,35 \%$. Diartikan kesesuaian sebesar 96,35\% terhadap mekanik yang memiliki pengetahuan yang baik tentang kendaraan.

Tabel 13

Kenyataan dan Harapan responden terhadap keterampilan mekanik dalam memperbaiki kendaraan

\begin{tabular}{|c|c|c|c|c|c|c|}
\hline $\begin{array}{c}\text { Kondi } \\
\text { si }\end{array}$ & $\begin{array}{c}\text { Sang } \\
\text { at } \\
\text { Pent } \\
\text { ing }\end{array}$ & $\begin{array}{c}\text { Pent } \\
\text { ing }\end{array}$ & $\begin{array}{c}\text { Cuk } \\
\text { up } \\
\text { Pent } \\
\text { ing }\end{array}$ & $\begin{array}{c}\text { Kur } \\
\text { ang } \\
\text { Penti } \\
\text { ng }\end{array}$ & $\begin{array}{c}\text { Tida } \\
\text { k } \\
\text { pent } \\
\text { ing }\end{array}$ & $\begin{array}{c}\text { Bo } \\
\text { bot }\end{array}$ \\
\hline $\begin{array}{c}\text { Kenya } \\
\text { taan }\end{array}$ & 38 & 25 & 16 & 15 & 0 & 380 \\
\hline $\begin{array}{c}\text { Harap } \\
\text { an }\end{array}$ & 56 & 20 & 10 & 8 & 0 & 406 \\
\hline
\end{tabular}

Sumber : Data Olahan 2013

Dari data diatas didapat hasil jawaban responden diperoleh tingkat kesesuaiannya $=$ $(380 / 406) \times 100 \%=\mathbf{9 3 , 5 9 \%}$. Diartikan 
kesesuaian sebesar $\mathbf{9 3 , 5 9 \%}$ terhadap ketrampilan mekanik dalam memperbaiki kendaraan.

\section{Analisis Variabel Reabelity (Kehandalan)}

Tabel 14

Kenyataan dan Harapan responden terhadap

Penyelesaian pekerjaan memperbaiki kerusakan

\begin{tabular}{|c|c|c|c|c|c|c|}
\hline $\begin{array}{c}\text { Kondi } \\
\text { si }\end{array}$ & $\begin{array}{c}\text { Sang } \\
\text { at } \\
\text { pent } \\
\text { ing }\end{array}$ & $\begin{array}{c}\text { Pent } \\
\text { ing }\end{array}$ & $\begin{array}{c}\text { Cuk } \\
\text { up } \\
\text { Pent } \\
\text { ing }\end{array}$ & $\begin{array}{c}\text { Kur } \\
\text { ang } \\
\text { Penti } \\
\text { ng }\end{array}$ & $\begin{array}{c}\text { Tida } \\
\text { k } \\
\text { pent } \\
\text { ing }\end{array}$ & $\begin{array}{c}\text { Bo } \\
\text { bot }\end{array}$ \\
\hline $\begin{array}{c}\text { Kenya } \\
\text { taan }\end{array}$ & 56 & 20 & 12 & 6 & 0 & 408 \\
\hline $\begin{array}{c}\text { Harap } \\
\text { an }\end{array}$ & 62 & 18 & 6 & 8 & 0 & 416 \\
\hline
\end{tabular}

Sumber : Data Olahan2013

Dari data diatas didapat hasil jawaban responden diperoleh tingkat kesesuaiannya = $(408 / 416)$ x $100 \%=\mathbf{9 8 , 0 8 \%}$. Diartikan kesesuaian sebesar $\mathbf{9 8 , 0 8 \%}$ terhadap penyelesaian pekerjaan memperbaiki kerusakan.

Tabel 15

Kenyataan dan Harapan responden terhadap Perkiraan Biaya sesuai dengan yang dibayar pada saat pembayaran

\begin{tabular}{|c|c|c|c|c|c|c|}
\hline $\begin{array}{c}\text { Kondi } \\
\text { si }\end{array}$ & $\begin{array}{c}\text { Sang } \\
\text { at } \\
\text { Pent } \\
\text { ing }\end{array}$ & $\begin{array}{c}\text { Pent } \\
\text { ing }\end{array}$ & $\begin{array}{c}\text { Cuk } \\
\text { up } \\
\text { Pent } \\
\text { ing }\end{array}$ & $\begin{array}{c}\text { Kur } \\
\text { ang } \\
\text { penti } \\
\text { ng }\end{array}$ & $\begin{array}{c}\text { Tida } \\
\text { k } \\
\text { pent } \\
\text { ing }\end{array}$ & $\begin{array}{c}\text { Bo } \\
\text { bot }\end{array}$ \\
\hline $\begin{array}{c}\text { Kenya } \\
\text { taan }\end{array}$ & 51 & 18 & 15 & 10 & 0 & 392 \\
\hline $\begin{array}{c}\text { Harap } \\
\text { an }\end{array}$ & 58 & 23 & 13 & 0 & 0 & 421 \\
\hline
\end{tabular}

Sumber : Data Olahan 2013

Dari data diatas didapat hasil jawaban responden diperoleh tingkat kesesuaiannya $=$ $(392 / 421)$ x $100 \%=\mathbf{9 3 , 1 1 \%}$. Diartikan kesesuaian sebesar $\mathbf{9 3 , 1 1 \%}$ terhadap perkiraan biaya sesuai dengan yang dibayar pada saat pembayaran.
Tabel 16

Kenyataan dan Harapan responden terhadap Petugas melaksanakan prosedur kerja yang sistematis

\begin{tabular}{|c|c|c|c|c|c|c|}
\hline $\begin{array}{c}\text { Kondi } \\
\text { si }\end{array}$ & $\begin{array}{c}\text { Sang } \\
\text { at } \\
\text { Pent } \\
\text { ing }\end{array}$ & $\begin{array}{c}\text { Pent } \\
\text { ing }\end{array}$ & $\begin{array}{c}\text { Cuk } \\
\text { up } \\
\text { Pent } \\
\text { ing }\end{array}$ & $\begin{array}{c}\text { Kur } \\
\text { ang } \\
\text { penti } \\
\text { ng }\end{array}$ & $\begin{array}{c}\text { Tida } \\
\mathbf{k} \\
\text { pent } \\
\text { ing }\end{array}$ & $\begin{array}{c}\text { Bo } \\
\text { bot }\end{array}$ \\
\hline $\begin{array}{c}\text { Kenya } \\
\text { taan }\end{array}$ & 53 & 10 & 19 & 12 & 0 & 386 \\
\hline $\begin{array}{c}\text { Harap } \\
\text { an }\end{array}$ & 69 & 13 & 12 & 0 & 0 & 433 \\
\hline
\end{tabular}

Sumber : Data Olahan 2013

Dari data diatas didapat hasil jawaban responden diperoleh tingkat kesesuaiannya $=$ $(386 / 433) \times 100 \%=\mathbf{8 9 , 1 5 \%}$. Diartikan kesesuaian sebesar $\mathbf{8 9 , 1 5 \%}$ terhadap petugas melaksanakan prosedur kerja yang sistematis.

Tabel 17

Kenyataan dan Harapan responden terhadap Pelanggan yang lebih dahulu memperoleh layanan lebih dahulu

\begin{tabular}{|c|c|c|c|c|c|c|}
\hline $\begin{array}{c}\text { Kondi } \\
\text { si }\end{array}$ & $\begin{array}{c}\text { Sang } \\
\text { at } \\
\text { Pent } \\
\text { ing }\end{array}$ & $\begin{array}{c}\text { Pent } \\
\text { ing }\end{array}$ & $\begin{array}{c}\text { Cuk } \\
\text { up } \\
\text { Pent } \\
\text { ing }\end{array}$ & $\begin{array}{c}\text { Kur } \\
\text { ang } \\
\text { Penti } \\
\text { ng }\end{array}$ & $\begin{array}{c}\text { Tida } \\
\text { k } \\
\text { pent } \\
\text { ing }\end{array}$ & $\begin{array}{c}\text { Bo } \\
\text { bot }\end{array}$ \\
\hline $\begin{array}{c}\text { Kenya } \\
\text { taan }\end{array}$ & 63 & 13 & 6 & 12 & 0 & 409 \\
\hline $\begin{array}{c}\text { Harap } \\
\text { an }\end{array}$ & 70 & 10 & 6 & 8 & 0 & 424 \\
\hline
\end{tabular}

Sumber : Data Olahan 2013

Dari data diatas didapat hasil jawaban responden diperoleh tingkat kesesuaiannya = $(409 / 424)$ x $100 \%=\mathbf{9 6 , 4 6 \%}$. Diartikan kesesuaian sebesar $\mathbf{9 6 , 4 6 \%}$ terhadap terhadap pelanggan yang lebih dahulu memperoleh layanan lebih dahulu. 
memberikan beberapa pilihan peralatan yang dapat dipergunakan.

\section{Analisis variabel Responsiveness (Ketanggapan)}

Tabel 18

Kenyataan dan Harapan Responden Terhadap Petugas Memberikan Konsultasi Gratis Tentang Kerusakan Kendaraan

\begin{tabular}{|c|c|c|c|c|c|c|}
\hline $\begin{array}{c}\text { Kondi } \\
\text { si }\end{array}$ & $\begin{array}{c}\text { Sang } \\
\text { at } \\
\text { Pent } \\
\text { ing }\end{array}$ & $\begin{array}{c}\text { Pent } \\
\text { ing }\end{array}$ & $\begin{array}{c}\text { Cuk } \\
\text { up } \\
\text { Pent } \\
\text { ing }\end{array}$ & $\begin{array}{c}\text { Kur } \\
\text { ang } \\
\text { Penti } \\
\text { ng }\end{array}$ & $\begin{array}{c}\text { Tida } \\
\text { k } \\
\text { pent } \\
\text { ing }\end{array}$ & $\begin{array}{c}\text { Bo } \\
\text { bot }\end{array}$ \\
\hline $\begin{array}{c}\text { Kenya } \\
\text { taan }\end{array}$ & 44 & 25 & 13 & 12 & 0 & 383 \\
\hline $\begin{array}{c}\text { Harap } \\
\text { an }\end{array}$ & 60 & 17 & 13 & 4 & 0 & 415 \\
\hline
\end{tabular}

Sumber : Data Olahan 2013

Dari data diatas didapat hasil jawaban responden diperoleh tingkat kesesuaiannya = $(383 / 415)$ x $100 \%=\mathbf{9 2 , 2 9 \%}$. Diartikan kesesuaian sebesar $\mathbf{9 2 , 2 9 \%}$ terhadap petugas memberikan konsultasi gratis tentang kerusakan kendaraan.

Tabel 19

Kenyataan dan Harapan Responden Terhadap

Petugas Memberikan Beberapa Pilihan Peralatan Yang Dapat Dipergunakan

\begin{tabular}{|c|c|c|c|c|c|c|}
\hline $\begin{array}{c}\text { Kondi } \\
\text { si }\end{array}$ & $\begin{array}{c}\text { Sang } \\
\text { at } \\
\text { Pent } \\
\text { ing }\end{array}$ & $\begin{array}{c}\text { Pent } \\
\text { ing }\end{array}$ & $\begin{array}{c}\text { Cuk } \\
\text { up } \\
\text { Pent } \\
\text { ing }\end{array}$ & $\begin{array}{c}\text { Kur } \\
\text { ang } \\
\text { Penti } \\
\text { ng }\end{array}$ & $\begin{array}{c}\text { Tida } \\
\text { k } \\
\text { pent } \\
\text { ing }\end{array}$ & $\begin{array}{c}\text { Bo } \\
\text { bot }\end{array}$ \\
\hline $\begin{array}{c}\text { Kenya } \\
\text { taan }\end{array}$ & 35 & 17 & 18 & 24 & 0 & 345 \\
\hline $\begin{array}{c}\text { Harap } \\
\text { an }\end{array}$ & 49 & 22 & 9 & 14 & 0 & 388 \\
\hline
\end{tabular}

Sumber : Data Olahan 2013

Dari data diatas didapat hasil jawaban responden diperoleh tingkat kesesuaiannya $=$ $(345 / 388) \times 100 \%=\mathbf{8 8 , 9 2 \%}$. Diartikan kesesuaian sebesar $\mathbf{8 8 , 9 6 \%}$ terhadap petugas
Tabel 20

Kenyataan dan Harapan Responden Terhadap Petugas Memberi Pengertian Tentang Komplain Pelanggan

\begin{tabular}{|c|c|c|c|c|c|c|}
\hline $\begin{array}{c}\text { Kondi } \\
\text { si }\end{array}$ & $\begin{array}{c}\text { Sang } \\
\text { at } \\
\text { Pent } \\
\text { ing }\end{array}$ & $\begin{array}{c}\text { Pent } \\
\text { ing }\end{array}$ & $\begin{array}{c}\text { Cuk } \\
\text { up } \\
\text { Pent } \\
\text { ing }\end{array}$ & $\begin{array}{c}\text { Kur } \\
\text { ang } \\
\text { Penti } \\
\text { ng }\end{array}$ & $\begin{array}{c}\text { Tida } \\
\text { k } \\
\text { pent } \\
\text { ing }\end{array}$ & $\begin{array}{c}\text { Bo } \\
\text { bot }\end{array}$ \\
\hline $\begin{array}{c}\text { Kenya } \\
\text { taan }\end{array}$ & 56 & 18 & 10 & 10 & 0 & 402 \\
\hline $\begin{array}{c}\text { Harap } \\
\text { an }\end{array}$ & 62 & 13 & 16 & 5 & 0 & 420 \\
\hline
\end{tabular}

Sumber : Data Olahan 2013

Dari data diatas didapat hasil jawaban responden diperoleh tingkat kesesuaiannya $=(402 / 420) \times 100 \%=\mathbf{9 5 , 7 1 \%}$. Diartikan kesesuaian sebesar $\mathbf{9 5 , 7 1 \%}$ terhadap petugas memberi pengertian tentang komplain pelanggan.

Tabel 21

Kenyataan dan Harapan Responden Terhadap Petugas Berusaha Memperbaiki Kesalahan Di Dalam Melayani Pelanggan

\begin{tabular}{|c|c|c|c|c|c|c|}
\hline $\begin{array}{c}\text { Kondi } \\
\text { si }\end{array}$ & $\begin{array}{c}\text { Sang } \\
\text { at } \\
\text { Pent } \\
\text { ing }\end{array}$ & $\begin{array}{c}\text { Pent } \\
\text { ing }\end{array}$ & $\begin{array}{c}\text { Cuk } \\
\text { up } \\
\text { Pent } \\
\text { ing }\end{array}$ & $\begin{array}{c}\text { Kur } \\
\text { ang } \\
\text { Penti } \\
\text { ng }\end{array}$ & $\begin{array}{c}\text { Tida } \\
\text { k } \\
\text { pent } \\
\text { ing }\end{array}$ & $\begin{array}{c}\text { Bo } \\
\text { bot }\end{array}$ \\
\hline $\begin{array}{c}\text { Kenya } \\
\text { taan }\end{array}$ & 51 & 20 & 23 & 0 & 0 & 404 \\
\hline $\begin{array}{c}\text { Harap } \\
\text { an }\end{array}$ & 60 & 15 & 19 & 0 & 0 & 417 \\
\hline
\end{tabular}

Sumber : Data Olahan 2013

Dari data diatas didapat hasil jawaban responden diperoleh tingkat kesesuaiannya = $(404 / 417)$ x $100 \%=\mathbf{9 6 , 8 8 \%}$. Diartikan kesesuaian sebesar $\mathbf{9 6 , 8 8 \%}$ terhadap petugas berusaha memperbaiki kesalahan di dalam melayani pelanggan. 


\section{Analisis Empathy (Empati)}

Tabel 22

Kenyataan dan Harapan Responden Terhadap Jawaban Masalah Kerusakan Dengan Tepat

\begin{tabular}{|c|c|c|c|c|c|c|}
\hline $\begin{array}{c}\text { Kondi } \\
\text { si }\end{array}$ & $\begin{array}{c}\text { Sang } \\
\text { at } \\
\text { Pent } \\
\text { ing }\end{array}$ & $\begin{array}{c}\text { Pent } \\
\text { ing }\end{array}$ & $\begin{array}{c}\text { Cuk } \\
\text { Pent } \\
\text { Peng }\end{array}$ & $\begin{array}{c}\text { Kur } \\
\text { ang } \\
\text { Penti } \\
\text { ng }\end{array}$ & $\begin{array}{c}\text { Tida } \\
\text { k } \\
\text { pent } \\
\text { ing }\end{array}$ & $\begin{array}{c}\text { Bo } \\
\text { bot }\end{array}$ \\
\hline $\begin{array}{c}\text { Kenya } \\
\text { taan }\end{array}$ & 56 & 20 & 0 & 18 & 0 & 396 \\
\hline $\begin{array}{c}\text { Harap } \\
\text { an }\end{array}$ & 65 & 26 & 1 & 2 & 0 & 436 \\
\hline
\end{tabular}

Sumber : Data Olahan 2013

Dari data diatas didapat hasil jawaban responden diperoleh tingkat kesesuaiannya $=$ $(396 / 436) \times 100 \%=\mathbf{9 0 , 8 2 \%}$. Diartikan kesesuaian sebesar $\mathbf{9 0 , 8 2 \%}$ terhadap jawaban masalah kerusakan dengan tepat.

Tabel 23

Kenyataan dan Harapan Responden Terhadap Pemberian Alternatif Dengan Kemampuan Financial Pelanggan

\begin{tabular}{|c|c|c|c|c|c|c|}
\hline $\begin{array}{c}\text { Kondi } \\
\text { si }\end{array}$ & $\begin{array}{c}\text { Sang } \\
\text { at } \\
\text { Pent } \\
\text { ing }\end{array}$ & $\begin{array}{c}\text { Pent } \\
\text { ing }\end{array}$ & $\begin{array}{c}\text { Cuk } \\
\text { up } \\
\text { Pent } \\
\text { ing }\end{array}$ & $\begin{array}{c}\text { Kur } \\
\text { ang } \\
\text { Penti } \\
\text { ng }\end{array}$ & $\begin{array}{c}\text { Tida } \\
\text { k } \\
\text { pent } \\
\text { ing }\end{array}$ & $\begin{array}{c}\text { Bo } \\
\text { bot }\end{array}$ \\
\hline $\begin{array}{c}\text { Kenya } \\
\text { taan }\end{array}$ & 42 & 28 & 7 & 17 & 0 & 377 \\
\hline $\begin{array}{c}\text { Harap } \\
\text { an }\end{array}$ & 51 & 27 & 14 & 2 & 0 & 409 \\
\hline
\end{tabular}

\section{Sumber : Data Olahan}

Dari data diatas didapat hasil jawaban responden diperoleh tingkat kesesuaiannya $=$ $(377 / 409) \times 100 \%=\mathbf{9 2 , 1 8 \%}$. Diartikan kesesuaian sebesar $\mathbf{9 2 , 1 8 \%}$ terhadap pemberian alternative dengan kemampuan financial pelanggan.

\section{Rekapitulasi Rata-rata Kenyataan dan Harapan}

Rekapitulasi rata-rata kenyataan dan Harapan pelanggan pada faktor-faktor yang mempengaruhi kepuasan pelanggan dapat dilihat pada tabel dibawah ini:

Tabel 24

Perhitungan Rata-Rata Kenyataan dan Harapan Pada Faktor Yang Mempengaruhi

Kepuasan Pelanggan Bengkel Anto Motor

\begin{tabular}{|c|c|c|c|c|c|}
\hline No & Variabel & $\begin{array}{c}\text { Ken } \\
\text { yata } \\
\text { an }\end{array}$ & $\begin{array}{l}\text { Har } \\
\text { apan }\end{array}$ & $\mathbf{X}$ & $\mathbf{Y}$ \\
\hline I & Tangible & & & & \\
\hline 1 & $\begin{array}{l}\text { Lokasi Bengkel } \\
\text { yang Strategis }\end{array}$ & 390 & 421 & 4,15 & 4,48 \\
\hline 2 & $\begin{array}{lr}\text { Kondisi } & \text { Bengkel } \\
\text { Menarik } & \text { dan } \\
\text { Kokoh } & \\
\end{array}$ & 372 & 401 & 3,96 & 4,26 \\
\hline 3 & $\begin{array}{l}\text { Memiliki } \\
\text { kelengkapan } \\
\text { sparepart dan } \\
\text { peralatan }\end{array}$ & 383 & 417 & 4,07 & 4,44 \\
\hline 4 & $\begin{array}{l}\text { Fasilitas bengkel } \\
\text { unggul dibanding } \\
\text { bengkel lain. }\end{array}$ & 394 & 423 & 4,20 & 4,50 \\
\hline II & Assurance & & & & \\
\hline 5 & $\begin{array}{l}\text { Jumlah mekanik } \\
\text { yang memadai }\end{array}$ & 387 & 418 & 4,12 & 4,45 \\
\hline 6 & $\begin{array}{l}\text { Mekanik yang } \\
\text { sigap }\end{array}$ & 365 & 406 & 3,88 & 4,32 \\
\hline 7 & $\begin{array}{l}\text { Memiliki } \\
\text { pengetahuan baik } \\
\text { tenteng kendaraan }\end{array}$ & 396 & 411 & 4,20 & 4,37 \\
\hline 8 & $\begin{array}{l}\text { Mekanik terampil } \\
\text { memperbaiki } \\
\text { kendaraan. }\end{array}$ & 380 & 406 & 4,04 & 4,32 \\
\hline III & Realibility & & & & \\
\hline 9 & $\begin{array}{l}\text { Penyelesaian } \\
\text { pekerjaan } \\
\text { memperbaiki } \\
\text { kerusakan }\end{array}$ & 408 & 416 & 4,34 & 4,42 \\
\hline 10 & $\begin{array}{l}\text { Perkiraan Biaya } \\
\text { yang sesuai }\end{array}$ & 392 & 421 & 4,17 & 4,48 \\
\hline 11 & $\begin{array}{l}\text { Prosedur kerja } \\
\text { yang sistematis }\end{array}$ & 386 & 433 & 4,11 & 4,61 \\
\hline 12 & $\begin{array}{l}\text { Pelanggan yang } \\
\text { lebih dahulu, } \\
\text { memperoleh } \\
\text { dahulu pelayanan. }\end{array}$ & 409 & 424 & 4,35 & 4,50 \\
\hline IV & Responsiveness & & & & \\
\hline 13 & $\begin{array}{l}\text { Konsultasi gratis } \\
\text { tentang kerusakan }\end{array}$ & 383 & 415 & 4,07 & 4,41 \\
\hline 14 & $\begin{array}{l}\text { Memberikan } \\
\text { beberapa pilihan }\end{array}$ & 345 & 388 & 3,67 & 4,13 \\
\hline
\end{tabular}




\begin{tabular}{|c|l|l|l|l|l|}
\hline & peralatan & & & & \\
\hline 15 & $\begin{array}{l}\text { Memberi } \\
\text { pengertian tentang } \\
\text { komplain } \\
\text { pelanggan }\end{array}$ & 402 & 420 & 4,28 & 4,47 \\
\hline 16 & $\begin{array}{l}\text { Memperbaiki } \\
\text { kesalahan yang } \\
\text { dilakukan }\end{array}$ & 404 & 417 & 4,29 & 4,43 \\
\hline V & Emphaty & & & \\
\hline 17 & $\begin{array}{l}\text { Memberikan } \\
\text { informasi terhadap } \\
\text { kerusakan }\end{array}$ & 413 & 427 & 4,39 & 4,54 \\
\hline 18 & $\begin{array}{l}\text { Memberi } \\
\text { informasi tentang } \\
\text { perkiraan biaya }\end{array}$ & 398 & 418 & 4,23 & 4,45 \\
\hline 19 & $\begin{array}{l}\text { Memberikan } \\
\text { jawaban masalah } \\
\text { kerusakan }\end{array}$ & 396 & 436 & 4,21 & 4,64 \\
\hline 20 & $\begin{array}{l}\text { Memberi alternatif } \\
\text { dalam perbaiki } \\
\text { kendaraan }\end{array}$ & 377 & 409 & 4,01 & 4,35 \\
\hline & $\begin{array}{l}\text { Rata-rata X dan } \\
\text { Y }\end{array}$ & & 3,93 & 4,43 \\
\hline
\end{tabular}

Sumber : data olahan

\section{Diagram Kartesius Faktor-Faktor yang Mempengaruhi Keputusan Pelanggan}

Gambar 2

Diagram Kartesius Faktor-Faktor yang Mempengaruhi Kepuasan Pelanggan pada Bengkel Anto Motor Pekanbaru

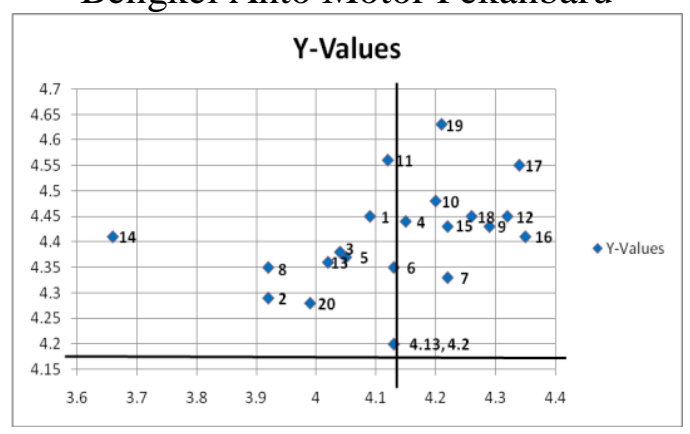

Keterangan :

Berdasarkan diagram diatas dari pengolahan data yang diperoleh berdasarkan variabel yang digunakan, maka penulis mengambil suatu kesimpulan:

1. Pada diagram posisi A (Prioritas Utama) yaitu Prioritas atau atribut yang dianggap mempengaruhi kepuasan pelanggan ada beberapa yang berjalan dianggap belum dilaksanakan sesuai dengan keinginan konsumen seperti halnya kondisi bengkel kurang menjadi perhatian dan kemenarikan daripada pelanggan belum dilakukan secara maksimal oleh pihak bengkel. Disamping hal itu juga kesigapan mekanik dalam melayani pelanggan masih kurang sehingga harus menjadikan perhatian yang lebih baik bagi pihak bengkel.

2. Pada diagram posisi B (Pertahankan prestasi) yaitu atribut yang dianggap mempengaruhi kepuasan pelanggan sudah berjalan sesuai daripada perencanaan yang diharapkan. Dimana beberapa pertanyaan pada setiap variabel telah menunjukan sesuai dengan harapan dan kenyataan yang diinginkan atau diharapkan oleh pihak pelanggan terhadap apa yang sudah dilakukan oleh pihak bengkel Anto Motor Pekanbaru seperti pada variabel Jaminan, Kehandalan, Ketanggapan serta Empati.

3. Pada diagram posisi C (Prioritas Rendah) dan posisi diagram $\mathrm{D}$ (Berlebihan) tidak menunjukan adanya posisi tanggapan responden terhadap variabel-variabel yang digunakan dalam penelitian ini memberi pengaruh terhadap harapan yang diinginkan oleh konsumen terhadap kenyataan yang ada pada bengkel Anto Motor Pekanbaru.

\section{KESIMPULAN DAN SARAN Kesimpulan}

Berdasarkan hasil penelitian dan pembahasan yang telah diuraikan, maka penulis menarik kesimpulan :

1. Faktor Tangibels, bahwa lokasi yang strategis dan kondisi bengkel yang menarik dan kokoh memenuhi harapan pelanggan dengan hasil 93,64\%, 91,85\% terhadap kelengkapan fasilitas seperti spare part dan peralatan perbaikan, 93,14\% terhadap kelengkapan fasilitas dibandingkan bengkel lain. 
2. Faktor Assurance, bahwa harapan sebagian besar dari responden memiliki kesesuaian sebesar $92,58 \%$ terhadap mekanik dengan jumlah yang memadai, $89,90 \%$ terhadap mekanik yang sigap melayani pelanggan,96,35\% terhadap mekanik yang memiliki pengetahuan yang baik tentang kendaraan dan $93,59 \%$ terhadap ketrampilan mekanik dalam memperbaiki kendaraan.

3. Faktor Reabelity, bahwa sebesar $98,08 \%$ terhadap penyelesaian pekerjaan memperbaiki kerusakan, 93,11\% terhadap perkiraan biaya sesuai dengan yang dibayar pada saat pembayaran, $89,15 \%$ terhadap petugas melaksanakan prosedur kerja yang sistematis, dan 96,46\% terhadap terhadap pelanggan yang lebih dahulu memperoleh layanan lebih dahulu.

4. Faktor Responsiveness, bahwa sebesar $92,29 \%$ terhadap petugas memberikan konsultasi gratis tentang kerusakan kendaraan, $88,96 \%$ terhadap petugas memberikan beberapa pilihan peralatan yang dapat dipergunakan, 95,71\% terhadap petugas memberi pengertian tentang komplain pelanggan dan 96,88\% terhadap petugas berusaha memperbaiki kesalahan di dalam melayani pelanggan.

5. Faktor Empathy, bahwa sebesar 96,72\% terhadap informasi kerusakan kendaraan secara mendetail, $95,21 \%$ terhadap informasi tentang perkiraan biaya yang dikeluarkan pelanggan, 90,82\% terhadap jawaban masalah kerusakan dengan tepat dan $92,18 \%$ terhadap pemberian alternative dengan kemapuan financial pelanggan.

\section{Saran}

1. Bahwa faktor Tangibels, Assurance, Reliability, Responsiveness, dan Empathy, berpengaruh positif terhadap kepuasan pelanggan pada Bengkel Anto Motor Pekanbaru. Maka disarankan pada pihak Bengkel untuk mempertahankan jumlah pelanggannya dengan cara meningkatkan pelayanan.

2. Hal yang perlu diperhatikan lagi apabila terjadi penurunan jumlah pelanggan dibandingkan dengan tahun sebelumnya, hendaknya pihak bengkel perlu memperhatikan kembali faktor-faktor apa saja penyebab terjadi penurunan jumlah Pelanggan pada Bengkel Anto Motor Pekanbaru.

3. Bahwa faktor Tangibels perlu ditingkatkan lagi guna menarik perhatian pelanggan dengan cara melakukan renovasi bangunan yang kokoh.

\section{DAFTAR PUSTAKA}

Adrian, Payne, (2000), Pemasaran Jasa, The Essence of Service Marketing, Yogyakarta, Andi

Anatan, Lina \& Lena Ellitan. (2008), Supply Chain Management Teori dan Aplikasi, Bandung, Alfabeta.

Atep, Adya, Barata, 2004, Dasar-dasar Pelayanan Prima, Jakarta, Elex Media Komputindo.

Fandy, Tjiptono. (2005), Pemasaran Jasa, edisi pertama, Malang, Bayu Media Publishing

, (2000), Manajemen Jasa, Yogyakarta, Penerbit Andi , (2004), Manajemen Jasa Yogyakarta : Penerbit Andi

Freddy Rangkuti, (2006). Measuring Customer Satisfaction,(Teknik Mengukur dan Strategy Meningkatkan Kepuasan Pelanggan), serta Analisis PLN JP, Jakarta, Gramedia Pustaka Utama.

Handi Irawan, (2009). 10 Prinsip Kepuasan Pelanggan. Jakarta: PT. Elex Media, Komputindo

Husein Umar, 2003, Metodologi Penelitian Untuk Skripsi dan Tesis Bisnis, Jakarta, PT. Gramedia Pustaka.

John A. Martilla and John C. James, (1977), Important Performance Analysis The 
Journal Pf Marketing. Vol. 41, Published By Maerican Marketing, Association.

Kotler, Philip. 2002. Marketing Management, Millenium Edition North Western University New Jersey, Prentice Hall Inc.

Moenir, (2000), Manajemen Pelayanan Publik, Jakarta, Bina Aksara

Rambat Lupiyoadi \& A. Hamdani, (2006), Konsumen dan Jasa, Jakarta, Salemba Empat

Sugiyono, 2006, Statistika Untuk Penelitian, Bandung: Alfabeta , 2006, Metodologi Penelitian Bisnis, Bandung, Alfabeta 